\title{
PELANGGARAN PERLUASAN BANGUNAN DI KOMPLEKS PERUMAHAN DI KOTA SURABAYA DITINJAU DARI PERATURAN TENTANG GARIS SEMPADAN BANGUNAN
}

\author{
Suprapti, Niken Prasetyawati, \\ Ni Wayan Suarmini, Tony Hanuraga, Siti Zahrok
}

\begin{abstract}
Abstrak
Perumahan yang dibangun pengembang mulai dekade delapan-puluhan, pada awalnya dibangun sesuai dengan ketentuan tata ruang Kota Surabaya. Namun demikian dalam pengembangannya sesudah ditempati penghuni, rumah-rumah tersebut mengalami banyak perubahan; salah satunya adalah perluasan ke arah depan yang melebihi Garis Sempadan Bangunan (GSB). Perluasan yang tidak sesuai dengan rencana tata ruang kota merupakan pelanggaran GSB yang menyebabkan pemunduran bangunan menjadi tidak rapih; berkurangnya halaman depan dan ruang terbuka di dalam kaveling; serta membahayakan pengguna jalan yang akan berbelok karena pandangannya tertutup bangunan pada kaveling pojok. Masalah yang mendasar adalah, perubahan dan penambahan luas bangunan yang dilakukan pemilik rumah melanggar peraturan tentang GSB, baik peraturan pada tingkat undang-undang, peraturan pemerintah, keputusan menteri maupun peraturan walikota. Tujuan studi ini adalah mencari penyelesaian secara hukum terhadap pelanggaran GSB yang telah ditetapkan dalam peraturan perundangan dan rencana tata ruang melalui pendekatan kasus dengan cara mengevaluasi kondisi empiris lapangan terhadap peraturan mengenai GSB.

Usulan penyelesaiannya adalah (1) pelanggaran yang dilakukan sesudah diberlakukannya Perda Kota Surabaya No. 7 Tahun 2009 tentang Bangunan, yaitu pengenaan sangsi administrasi; (2) pelanggaran yang dilakukan sebelum diberlakukanya Perda Kota Surabaya No. 7 Tahun 2009 tentang Bangunan, ada dua penyelesaian, yaitu (a) pelanggaran yang dilakukan pemilik bangunan yang mengajukan pembaruan IMB atau pemutihan IMB, sangsinya adalah membayar denda atas pelanggaran dan mengembalikan posisi GSB sesuai ketentuan yang berlaku; (b) pelanggaran yang dilakukan pemilik bangunan yang tidak melakukan perubahan apapun, tidak dikenakan sangsi apapun tetapi bisa digugat jika atas pelanggaran tersebut menimbulkan kerugian pada orang lain, atau dikenakan disinsentif berupa denda yang diberlakukan setiap tahun.
\end{abstract}

Kata kunci : perluasan bangunan, pelanggaran, GSB

Pembangunan perumahan oleh pengembang di Surabaya mulai marak pada dekade delapan-puluhan yang ditandai dengan pembangunan perumahan berbagai tipe, antara lain tipe 56/120; tipe 70/135; tipe 70/200; dan tipe-tipe dengan luas kaveling lebih besar dari $200 \mathrm{~m} 2$ yang dibangun berdasarkan pesanan pembeli. Pada saat dibangun, perumahan tersebut telah disesuaikan dengan ketentuan yang ditetapkan oleh Pemerintah Kota Surabaya. Salah satunya adalah ketentuan mengenai Garis Sempadan Bangunan. Sesudah dibangun dan ditempati pembeli, banyak di antaranya yang dirubah dan diperluas baik ke arah

jsh Jurnal Sosial Humaniora, Vol 5 No.1, Juni 2012 
depan, belakang maupun ke atas; dengan alasan bangunan kurang luas dan tidak mencukupi kebutuhan keluarga; susunan denah tidak sesuai keinginan; model atau tampilan bangunan tidak sesuai dengan selera. Perluasan tersebut salah satunya mengakibatkan terjadinya pelanggaran GSB, khususnya pada kaveling pojok, karena salah satu sisi bangunannya ditempatkan berimpit dengan pagar.

Perluasan yang melampaui batas GSB yang ditetapkan, merupakan pelanggaran yang mengakibatkan pemunduran bagian depan rumah tidak rapih, berkurangnya halaman depan dan ruang terbuka kaveling, serta membahayakan pengguna jalan yang akan berbelok. Ketidak-tegasan penindakan hukum terhadap pelanggaran ini mengakibatkan berkurang sampai hilangnya kewibawaan hukum di mata masyarakat, sehingga masyarakat yang tidak melanggar akan ikut-ikutan melakukan pelanggaran. Peraturan yang mengatur GSB adalah Undang-undang Nomor 28 Tahun 2002 tentang Bangunan Gedung; Peraturan Pemerintah Nomor 36 Tahun 2005 tentang Peraturan Pelaksanaan Undang-undang Nomor 28 Tahun 2002 tentang Bangunan Gedung; Keputusan Menteri Pekerjaan Umum Nomor 441/KPTS/1998 tentang Persyaratan Teknis Bangunan Gedung; Peraturan Daerah Kota Surabaya Nomor 7 Tahun 2009 tentang Bangunan; dan Peraturan Walikota Surabaya Nomor 73 Tahun 2009 tentang Tata Cara Pengenaan Sangsi Aministratif Pelanggaran Peraturan Daerah Kota Surabaya Nomor 7 tentang Bangunan. Berkaitan dengan hal tersebut, perlu dicarikan penyelesaian hukum dengan merujuk pada peraturan perundangan yang berlaku.

Garis Sempadan Bangunan atau disingkat GSB, adalah garis yang tidak boleh dilampaui oleh denah bangunan ke arah Garis Sempadan Pagar (GSP) yang ditetapkan dalam rencana kota (Perda Kota Surabaya No. 7 Tahun 2009 tentang Bangunan). Tujuan penyediaan GSB adalah untuk (1) keamanan pengguna jalan terutama di sekitar tikungan jalan; (2) penyediaan ruang terbuka di dalam kaveling untuk keperluan peresapan air ke dalam tanah; (3) pencahayaan sinar matahari; (4) penyediaan Ruang Terbuka Hijau; dan (4) kerapihan tatanan bangunan. 
Pelanggaran terhadap GSB mudah diidentifikasikan karena dinding bangunan berimpit dengan pagar atau GSB dibuat sama dengan nol. Pada hal berdasarkan rencana kota GSB ditetapkan minimal 3 meter.

\section{Peraturan yang Berkaitan dengan Garis Sempadan Bangunan}

Peraturan yang berkaitan dengan Garis Sempadan Bangunan adalah (1) Undang-undang Nomor 28 Tahun 2002 tentang Bangunan Gedung : (2) Peraturan Pemerintah Nomor 36 Tahun 2005 tentang Peraturan Pelaksanaan Undangundang Nomor 28 Tahun 2002 tentang Bangunan Gedung (3) Peraturan Menteri Pekerjaan Umum Nomor 29/PRT/M/2006 tentang Pedoman Persyaratan Teknis Bangunan Gedung[ (4) Peraturan Daerah Kota Surabaya Nomor 7 Tahun 2009 tentang Bangunan; dan (5) Peraturan Walikota Surabaya Nomor 73 Tahun 2009 tentang Tata Cara Pengenaan Sangsi Aministratif Pelanggaran Peraturan Daerah Kota Surabaya Nomor 7 tentang Bangunan. Penjelasannya adalah sebagai berikut.

\section{Undang-undang Nomor 28 Tahun 2002 tentang Bangunan Gedung}

Ketentuan mengenai GSB diatur dalam Bagian Ketiga, Persyaratan Tata Bangunan, Paragraf 2 Persyaratan Peruntukan dan Intensitas Bangunan Gedung, pasal 13.

Ketentuan dalam Undang-undang Nomor 28 Tahun 2002 yang relevan dengan substansi Garis Sempadan Bangunan.

a. Pasal 13 ayat (1); persyaratan jarak bebas bangunan gedung mencakup Garis Sempadan Bangunan gedung dengan as jalan.

b. Ketentuan mengenai persyaratan jarak bebas bangunan gedung diatur lebih lanjut dengan Peraturan Pemerintah.

\section{Peraturan Pemerintah Nomor 36 Tahun 2005 tentang Peraturan} Pelaksanaan Undang-undang Nomor 28 Tahun 2002 tentang Bangunan Gedung.

Ketentuan mengenai GSB diatur dalam Bagian Kedua Persyaratan

Administrasi Bangunan Gedung, Paragraf 4 tentang

Izin Mendirikan

Bangunan; pasal 14.

Ketentuan yang relevan dengan substansi Garis Sempadan Bangunan.

jsh Jurnal Sosial Humaniora, Vol 5 No.1, Juni 
60 - Pelanggaran Perluasan Bangunan di Kompleks Perumahan yang ........

a. Pasal 14 ayat (1); setiap orang yang akan mendirikan bangunan wajib memiliki Izin Mendirikan Bangunan.

b. Pasal 14 ayat (3); Pemerintah Daerah wajib memberikan Surat Keterangan Rencana Kabupaten/Kota untuk lokasi yang bersangkutan kepada setiap orang yang akan mengajukan permohonan IMB Gedung.

c. Pasal 14 ayat (4); Surat Keterangan Rencana Kabupaten/Kota merupakan ketentuan yang berlaku untuk lokasi yang bersangkutan dan berisi Garis Sempadan dan jarak bebas minimum bangunan yang diizinkan.

d. Pasal 21 ayat (1); setiap bangunan gedung yang didirikan tidak boleh melanggar ketentuan minimal jarak bebas bangunan gedung yang ditetapkan dalam Rencana Tata Ruang Wilayah

Kabupaten/Kota, Rencana Detail Tata Ruang Kawasan Perkotaan (RDTRKP) dan/atau Rencana Tata Bangunan dan Lingkungan (RTBL).

e. Pasal 21 ayat (2); ketentuan jarak bebas bangunan gedung ditetapkan dalam bentuk (1) GSB Gedung dengan as jalan $\quad$ (2) penetapan GSB Gedung dengan tepi jalan, didasarkan pada pertimbangan keselamatan dan kesehatan; (3) penetapan jarak antara as jalan dan pagar halaman yang diizinkan pada lokasi yang bersangkutan harus didasarkan pada pertimbangan keselamatan, kesehatan, kenyamanan, dan kemudahan; (4) ketentuan lebih lanjut mengenai tata cara penentuan besaran jarak bebas bangunan gedung diatur dengan Peraturan Menteri.

\section{Peraturan Menteri Pekerjaan Umum Nomor 29/PRT/M/2006 tentang Pedoman Persyaratan Teknis Bangunan Gedung.}

Ketentuan mengenai GSB diatur dalam Persyaratan Tata Bangunan dan Lingkungan, yaitu mengenai Intensitas Bangunan Gedung tentang Garis Sempadan (Muka) Bangunan.

Ketentuan yang relevan dengan substansi Garis Sempadan Bangunan.

a. GSB Gedung ditetapkan dalam rencana tata ruang, rencana tata bangunan dan lingkungan, serta peraturan bangunan setempat.

jsh Jurnal Sosial Humaniora, Vol 5 No.1, Jun 
b. Dalam mendirikan atau memperbarui seluruh atau sebagian dari suatu bangunan, GSB yang telah ditetapkan tidak boleh dilanggar.

c. Penetapan GSB didasarkan pada pertimbangan keamanan, kesehatan, kenyamanan, dan keserasian lingkungan serta ketinggian bangunan.

d. Daerah menetapkan garis sempadan muka bangunan, garis sempadan loteng.

e. Ketentuan mengenai besarnya GSB dapat diperbarui dengan pertimbangan perkembangan kota, kepentingan umum, keserasian dengan lingkungan, pertimbangan lain dengan mendengarkan pendapat teknis para ahli terkait.

\section{Peraturan Daerah Kota Surabaya Nomor 7 Tahun 2009 tentang Bangunan.}

Ketentuan yang berkaitan dengan GSB diatur dalam Bab III, Persyaratan

Bangunan; Bagian Kedua, Persyaratan Administrasi Bangunan; Paragraf 2.

Izin Mendirikan Bangunan, pasal 5 dan pasal 6.

Ketentuan yang relevan dengan substansi Garis Sempadan Bangunan.

a. Pasal 5 ayat (1); setiap orang atau badan yang akan mendirikan bangunan wajib memiliki Izin Mendirikan Bangunan.

b. Pasal 6 ayat (1); Surat Keterangan Rencana Kota merupakan ketentuan yang berlaku untuk lokasi yang bersangkutan dan berisi Garis Sempadan dan jarak bebas minimum bengunan yang diizinkan.

c. Pasal 13 ayat (1); Intensitas bangunan pada kawasan yang akan dibangun meliputi jarak bebas bangunan.

d. Pasal 13 ayat (4); jarak bebas bangunan adalah jarak bangunan dengan tepi rencana jalan (GSP).

e. Pasal 43 ayat (1); apabila pembangunan bangunan melanggar IMB beserta lampirannya dan/atau data yang dipergunakan sebagai persyaratan IMB ternyata palsu, maka Kepala Daerah berwenang (1) menghentikan sementara proses IMB; (2) mencabut IMB yang diterbitkan; (3) memerintahkan untuk menyesuaikan IMB yang ada; (4) memerintahkan pembongkaran bangunan.

jsh Jurnal Sosial Humaniora, Vol 5 No.1, Jun 
f. Pasal 45 ayat (2); apabila dalam pelaksanaan pembangunan bengunan terjadi ketidaksesuaian terhadap IMB dan/atau menimbulkan dampak negatif terhadap lingkungan, Pengawas Pelaksanaan Pembangunan Bangunan wajib menghentikan sementara pelaksanaan pembangunan serta melaporkan kepada pemilik dan/atau pengelola dan tembusannya disampaikan kepada Kepala Daerah melalui Pejabat yang berwenang menangani urusan di bidang bangunan.

g. Pasal 45 ayat (3); berdasarkan laporan Pengawas Pelaksanaan Pembangunan Bangunan, maka Kepala Daerah berwenang (1) melakukan penilaian terhadap kesesuaian IMB; (2) memerintahkan kepada pemilik untuk menunjuk pengkaji teknis melakukan kajian teknis apabila dalam pelaksanaan pembangunan bangunan terjadi ketidaksesuaian terhadap IMB dan/atau menimbulkan dampak negatif terhadap lingkungan.

h. Pasal 5 ayat (4); apabila berdasarkan hasil penilaian, pelaksanaan pembangunan secara teknis dapat dipertanggungjawabkan, Kepala Daerah dapat memberikan persetujuan untuk melanjutkan pelaksanaan pembangunan setelah mempertimbangkan aspek sosial dan lingkungan.

i. Pasal 46; pelaksanaan pembangunan bangunan yang menimbulkan kerugian pihak lain menjadi tanggung jawab pelaksana pembangunan dan/atau pemilik bangunan.

j. Pasal 72 ayat (2); sangsi administratif berupa (1) peringatan tertulis; (2) pembatasan kegiatan pembangunan; (3) penghentian sementara atau tetap pada pekerjaan pelaksanaan pembangunan; (4) penghentian sementara atu tetap terhadap pemanfaatan bangunan; (5) pembekuan IMB; (6) denda administrasi paling banyak Rp. 50.000.000; (7) pencabutan IMB; (8) pembekuan sertifikat laik fungsi; (9) pencabutan sertifikat laik fungsi; (10) penyegelan bangunan; (11) pembekuan atau pencabutan surat persetujuan pembongkaran bangunan; dan (12) pembongkaran bangunan.

\section{Peraturan Walikota Surabaya Nomor 73 Tahun 2009 tentang Tata Cara Pengenaan Sangsi Administratif Pelanggaran Peraturan Daerah Kota Surabaya Nomor 7 Tahun 2009 Tentang Bangunan.}


Ketentuan yang berkaitan dengan pemberian sangsi terhadap pelanggaran Peraturan Daerah Kota Surabaya Nomor 7 Tahun 2009 Tentang Bangunan adalah Bab II, Tata Cara Pemberian Sangsi Administratif; Bagian Kesatu, Umum; Pasal 2.

Pasal 2; setiap orang atau badan yang melakukan pelanggaran terhadap ketentuan dalam Pasal 72 ayat (1) Peraturan Daerah dan/atau peraturan pelaksanaan dari Peraturan Daerah, dikenakan sangsi administratif; berupa (a) peringatan tertulis; (b) pembatasan kegiatan pembangunan; (c) penghentian sementara atau tetap pada pekerjaan pelaksanaan pembangunan; (d) penghentian sementara atu tetap terhadap pemanfaatan bangunan; (e) pembekuan IMB; denda administrasi paling banyak Rp. 50.000.000; (g) pencabutan IMB; (h) pembekuan sertifikat laik fungsi; (i) pencabutan sertifikat laik fungsi; (j) penyegelan bangunan; (k) pembekuan atau pencabutan surat persetujuan pembongkaran bangunan; dan (1) pembongkaran bangunan.

\section{Pembahasan}

Studi ini masuk kategori doctrinal research melalui pendekatan kasus (Marzuki; 2005) dengan cara mengevaluasi kondisi empiris lapangan terhadap peraturan mengenai Garis Sempadan Bangunan, yaitu dengan melakukan kajian terhadap ketentuan dalam peraturan yang bersifat hirarkis untuk mendapatkan substansi pokok yang digunakan untuk mengevaluasi kondisi empiris di lapangan.

\section{Kajian terhadap peraturan mengenai Garis Sempadan Bangunan}

a. Undang-undang Nomor 28 Tahun 2002 tentang Bangunan Gedung menyebutkan bahwa GSB dihitung dari as jalan (pasal 13 ayat 1), sedangkan ketentuan mengenai persyaratan jarak bangunan (termaduk GSB) diatur dengan Peraturan Pemerintah (pasal13 ayat 3).

b. Peraturan Pemerintah Nomor 36 Tahun 2005 tentang Peraturan Pelaksanaan Undang-undang Nomor 28 Tahun 2002 tentang Bangunan Gedung, menyebutkan bahwa; 
(1). Setiap orang yang mendirikan bangunan wajib memiliki IMB (pasal 14 ayat 1 ) yang dikeluarkan oleh pemerintah daerah (pasal 14 ayat 2).

(2). Sebelum menerbitkan IMB pemerintah daerah wajib memberikan Surat Keterangan Rencana Kota (SKRK) sebagai dasar penerbitan IMB (pasal 14 ayat 3).

(3). Penetapan GSB tidak boleh melanggar ketentuan Rencana Tata Ruang Wilayah (RTRW) Kabupaten/Kota, Rencana Detail Tata Ruang Kawasan Perkotaan (RDTRKP) dan/atau Rencana Tata Bangunan dan Lingkungan (RTBL).

(4). Penetapan GSB dilakukan terhadap as jalan (pasal 21 ayat 2 butir 1) atau tepi jalan (pasal 21 ayat 2 butir 2) berdasarkan pertimbangan keselamatan dan kesehatan (pasal 21 ayat 3 butir 3); sedangkan ketentuan mengenai penentuan jarak bebas bangunan termasuk GSB diatur dengan Peraturan Menteri (pasal 21 ayat 2 butir 4).

c. Peraturan Menteri Pekerjaan Umum Nomor 29/PRT/M/2006 tentang

Pedoman Persyaratan Teknis Bangunan Gedung menyebutkan;

(1). GSB ditetapkan dalam rencana tata ruang, rencana tata bangunan dan lingkungan, serta peraturan bangunan setempat (butir a), dan tidak boleh dilanggar (butir b).

(2). Penetapan GSB didasarkan pada pertimbangan keamanan, kesehatan, kenyamanan, keserasian lingkungan, ketinggian bangunan (butir c).

(3). GSB meliputi GS Muka Bangunan dan GS Loteng (butir d).

(4). Besarnya GSB dapat diperbarui dengan pertimbangan perkembangan kota, kepentingan umum, keserasian dengan lingkungan, maupun pertimbangan lain dengan mendengarkan pendapat teknis para ahli terkait (butir e).

d. Peraturan Daerah Kota Surabaya Nomor 7 Tahun 2009 tentang Bangunan menyebutkan bahwa;

(1). Setiap orang atau badan yang akan mendirikan bangunan wajib memiliki IMB (pasal 5 ayat 1) yang harus dilengkapi dengan Surat 
Keterangan Rencana Kota (SKRK) yang mengatur GSB (pasal 6 ayat 1) yang dihitung dari tepi jalan (pasal 13 ayat 4).

(2). Apabila pembangunan melanggar IMB beserta lampirannya dan/atau data yang dipergunakan sebagai persyaratan IMB ternyata palsu, maka Kepala Daerah berwenang (a) menghentikan proses IMB; (b) mencabut IMB yang diterbitkan; (c) memerintahkan untuk menyesuaikan IMB yang ada; (d) memerintahkan pembongkaran bangunan. Dalam Peraturan Daerah ini yang dimaksud dengan "pembangunan bangunan" adalah proses pembangunan yang dilakukan pengawasan. Ketentuan ini tidak mengatur bangunan yang sudah dibangun tetapi melanggar IMB. Sesuai dengan prinsip "hukum tidak berlaku surut", maka terhadap bangunan yang melanggar tidak dapat dikenakan ketentuan dalam pasal 45 ayat 2 .

(3). Apabila dalam pelaksanaan pembangunan terjadi ketidaksesuaian terhadap IMB dan/atau menimbulkan dampak negatif terhadap lingkungan, Pengawas Pelaksanaan Pembangunan Bangunan wajib menghentikan sementara pelaksanaan pembangunan serta melaporkan kepada pemilik dan/atau pengelola dan tembusannya disampaikan kepada Kepala Daerah melalui Pejabat yang berwenang menangani urusan di bidang bangunan (pasal 45 ayat 2). Ketentuan ini berlaku bagi bangunan yang sedang dalam proses pelaksanaan pembangunan.

(4). Menurut pasal 45 ayat (3), berdasarkan laporan Pengawas

Pelaksanaan Pembangunan Bangunan, maka Kepala Daerah berwenang (a) melakukan penilaian terhadap kesesuaian IMB; dan (b) mmerintahkan kepada pemilik untuk menunjuk pengkaji teknis melakukan kajian teknis apabila dalam pelaksanaan pembangunan bangunan terjadi ketidaksesuaian terhadap IMB dan/atau menimbulkan dampak negatif terhadap lingkungan.

Jika berdasarkan hasil penilaian, pelaksanaan pembangunan secara teknis dapat dipertanggungjawabkan, Kepala Daerah dapat memberikan persetujuan untuk melanjutkan pelaksanaan 
pembangunan setelah mempertimbangkan aspek sosial dan lingkungan (pasal 45 ayat 4).

(5). Menurut pasal 72 ayat (2), pelanggaran terhadap peraturan daerah dikenakan sangsi administratif antara lain (a) peringatan tertulis; (b) pembatasan kegiatan pembangunan; (c) penghentian sementara atau tetap pada pekerjaan pelaksanaan pembangunan; (d) penghentian sementara atau tetap terhadap pemanfaatan bangunan; (e) pembekuan IMB; (f) denda administrasi paling banyak Rp. 50.000.000; (g) pencabutan IMB; (h) pembekuan sertifikat laik fungsi; (i) pencabutan sertifikat laik fungsi; (j) penyegelan bangunan; (k) pembekuan atau pencabutan surat persetujuan pembongkaran bangunan; dan (l) pembongkaran bangunan.

e. Peraturan Walikota Surabaya Nomor 73 Tahun 2009 tentang Tata Cara Pengenaan Sangsi Administratif Pelanggaran Peraturan Daerah Kota Surabaya Nomor 7 Tahun 2009 Tentang Bangunan; menyebutkan setiap orang atau badan yang melakukan pelanggaran terhadap ketentuan dalam Pasal 72 ayat (1) Peraturan Daerah dan/atau peraturan pelaksanaan dari Peraturan Daerah, dikenakan sangsi administratif, antara lain (1) peringatan tertulis; (2) pembatasan kegiatan pembangunan; penghentian sementara atau tetap pada pekerjaan pelaksanaan pembangunan; (4) penghentian sementara atu tetap terhadap pemanfaatan bangunan; (5) pembekuan IMB; (6) denda administrasi paling banyak Rp. 50.000.000; (7) pencabutan IMB; (8) pembekuan sertifikat laik fungsi; (9) pencabutan sertifikat laik fungsi; (10) penyegelan bangunan; (11) pembekuan atau pencabutan surat persetujuan pembongkaran bangunan; (12) pembongkaran bangunan.

Kesimpulan kajian peraturan :

a. Setiap orang yang mendirikan bangunan harus memiliki IMB.

b. Sebelum diterbitkan IMB, Pemerintah Daerah menerbitkan SKRK yang salah satunya mengatur tentang GSB. 
c. Besarnya GSB mengikuti ketentuan rencana tata ruang, yang meliputi Rencana Tata Ruang Wilayah (RTRW) Kota, Rencana Detail Tata Ruang Kota, dan/atau Rencana Tata Bangunan dan Lingkungan (RTBL).

d. Penetapan GSB didasarkan pada pertimbangan keamanan, kesehatan, kenyamanan, dan keserasian lingkungan serta ketinggian bangunan. e. Apabila pembangunan bangunan melanggar IMB beserta lampirannya dan/atau data yang dipergunakan sebagai persyaratan IMB ternyata palsu, maka Kepala Daerah berwenang (1) menghentikan proses IMB; (2) mencabut IMB yang diterbitkan; (3) memerintahkan untuk menyesuaikan IMB yang ada; (4) memerintahkan pembongkaran bangunan.

f. Jika dalam proses pelaksanaan pembangunan terjadi ketidaksesuaian terhadap IMB dan/atau menimbulkan dampak negatif terhadap lingkungan, Pengawas Pelaksanaan Pembangunan Bangunan wajib menghentikan sementara pelaksanaan pembangunan serta melaporkan kepada pemilik dan/atau pengelola dan tembusannya disampaikan kepada Kepala Daerah melalui Pejabat yang berwenang menangani urusan di bidang bangunan.

g. Jika berdasarkan laporan Pengawas Pelaksanaan Pembangunan Bangunan, maka Kepala Daerah berwenang (1) melakukan penilaian terhadap kesesuaian IMB; (2) memerintahkan kepada pemilik untuk menunjuk pengkaji teknis melakukan kajian teknis apabila dalam pelaksanaan pembangunan bangunan terjadi ketidaksesuaian terhadap IMB dan/atau menimbulkan dampak negatif terhadap lingkungan.

Jika berdasarkan hasil penilaian, pelaksanaan pembangunan secara teknis dapat dipertanggungjawabkan, Kepala Daerah dapat memberikan persetujuan untuk melanjutkan pelaksanaan pembangunan setelah mempertimbangkan aspek sosial dan lingkungan.

h. Pelanggaran terhadap Perda dikenakan sangsi administratif antara lain (1) peringatan tertulis; (2) pembatasan kegiatan pembangunan; penghentian sementara atau tetap pada pekerjaan pelaksanaan pembangunan; (4) penghentian sementara atu tetap terhadap pemanfaatan 
bangunan; (5) pembekuan IMB; (6) denda administrasi paling banyak Rp. 50.000.000; (7) pencabutan IMB; (8) pembekuan sertifikat laik fungsi; (9) pencabutan sertifikat laik fungsi; (10) penyegelan bangunan; (11) pembekuan atau pencabutan surat persetujuan pembongkaran bangunan; (12) pembongkaran bangunan.

\section{Kajian terhadap Pelanggaran GSB}

Kajian pelanggaran ditinjau terhadap Peraturan Daerah Kota Surabaya No. 7

Tahun 2009 tentang Bangunan.

a. Bangunan-bangunan yang dibangun sesudah diberlakukannya Perda No. 7

Tahun 2009, sangsi atas pelanggaran tersebut sudah jelas, yaitu sangsi administrasi sebagaimana diatur dalam pasal 72 ayat (2) Perda Kota Surabaya No. 7 Tahun 2009, dan pasal 2 Peraturan Walikota Surabaya Nomor 73 Tahun 2009, yaitu berupa (1) peringatan tertulis; (2) pembatasan kegiatan pembangunan; (3) penghentian sementara atau tetap pada pekerjaan pelaksanaan pembangunan; (4) penghentian sementara atau tetap terhadap pemanfaatan bangunan; (5) pembekuan IMB; (6) denda administrasi paling banyak Rp. 50.000.000; (7) pencabutan IMB; (8) pembekuan sertifikat laik fungsi; (9) pencabutan sertifikat laik fungsi; (10) penyegelan bangunan; (11) pembekuan atau pencabutan surat persetujuan pembongkaran bangunan; dan (12) pembongkaran bangunan.

b. Bangunan-bangungan yang melanggar tetapi dilakukan sebelum diberlakukannya Perda No. 7 Tahun 2009 tentang Bangunan, dikelompokkan menjadi dua kategori.

(1). Pelanggaran yang dilakukan pemilik bangunan yang mengajukan pembaruan IMB atau pemutihan IMB.

Perda No. 7 Tahun 2009 tidak mengatur pelanggaran yang dilakukan sebelum diberlakukannya perda tersebut. Namun demikian Pemerintah Kota Surabaya mempunyai cara untuk memberikan sangsi terhadap pelanggaran yang dilakukan oleh pemilik bangunan yang mengajukan pembaruan IMB atau pemutihan IMB; yaitu 
memberlakukan denda atas pelanggaran tersebut. Setelah bagian yang melanggar dibongkar sendiri oleh pemilik bangunan dan disesuaikan dengan ketentuan rencana kota yang berlaku, maka Pemerintah Kota Surabaya menerbitkan IMB berdasarkan ketentuan yang baru. Dalam hal ini sangsinya adalah membayar denda pelanggaran GSB dan membongkar sendiri bagian yang melanggar untuk disesuaikan dengan ketentuan yang berlaku. Langkah yang ditempuh Pemerintah Kota Surabaya merupakan yurisprudensi untuk memberikan sangsi kepada pelanggar GSB.

(2). Pelanggaran yang dilakukan pemilik bangunan yang tidak melakukan perubahan apapun.

Terhadap banganan-bangunan yang melakukan pelanggaran GSB sebelum diberlakukannya Perda No. 7 Tahun 2009 memang sulit untuk dikenakan sangsi. Ada dua hal yang bisa dilakukan.

(a). Membiarkan bangunan-bangunan yang melanggar tetap seperti apa adanya, asalkan pemilik bangunan tidak melakukan perubahan, pengembangan, perluasan terhadap bangunannya. Walaupun Pemerintah Kota Surabaya tidak memberikan sangsi, tetapi pemilik bangunan yang melakukan pelanggaran dapat digugat untuk membayar ganti kerugian jika atas pelanggaran GSB yang dilakukannya menimbulkan kerugian atau celaka kepada orang lain (misalnya orang yang mendapat kecelakaan karena pandangannya terhalang oleh bangunan yang melanggar GSB) sesuai Pasal 1365 KUH Perdata, yang berbunyi :

"Tiap perbuatan melanggar hukum yang membawa kerugian kepada seorang lain, mewajibkan orang yang karena salahnya menerbitkan kerugian itu, mengganti kerugian tersebut " (KUH Perdata dalam Hardjasumantri; 2002; hal 386).

Dalam hal ini orang yang dirugikan akan mendapat ganti kerugian jika ia bisa membuktikan bahwa kerugian tersebut benar-benar diakibatkan oleh pelanggaran yang dilakukan oleh pemilik bangunan.

jsh Jurnal Sosial Humaniora, Vol 5 No.1, Juni 
(b). Memberikan disinsentif dalam bentuk pengenaan denda yang diberlakukan setiap tahun. Dalam praktek, pengenaan denda tersebut tidak mudah, karena landasan yuridis untuk menentukan besaran denda atau penentuan tarif denda seringkali menimbulkan perdebatan hukum. Oleh karena itu penerapan disinsentif harus didahului dengan kajian akademis yang matang.

\section{Kesimpulan}

Usulan penyelesaian pelanggaran ditinjau terhadap peraturan perundangan yang berkaitan dengan GSB.

1. Bangunan-bangunan yang dibangun sesudah diterbitkannya Perda No. 7

Tahun 2009, sangsi atas pelanggaran didasarkan pada pasal 72 ayat (2) Perda Kota Surabaya No. 7 Tahun 2009, dan pasal 2 Peraturan Walikota Surabaya Nomor 73 Tahun 2009, yaitu berupa sangsi administratif.

2 Bangunan-bangunan yang dibangun sebelum diterbitkannya Perda No. 7

Tahun 2009.

a. Bangunan yang mengajukan IMB karena melakukan perluasan atau pemutihan. Sangsinya adalah membayar denda pelanggaran GSB dan membongkar sendiri bagian yang melanggar untuk disesuaikan dengan ketentuan yang berlaku.

b. Bangunan yang melanggar tetapi terhadap bangunan tidak dilakukan perubahan apapun. Penyelesaiannya adalah (1) tidak memberikan sangsi apapun, atau membiarkan bangunan-bangunan yang melanggar tetap seperti apa adanya, asalkan pemilik bangunan tidak melakukan perubahan, pengembangan, perluasan terhadap bangunannya. Namun demikian pemilik bangunan yang melakukan pelanggaran dapat digugat untuk membayar ganti kerugian, jika atas pelanggaran GSB yang dilakukannya menimbulkan kerugian atau celaka kepada orang lain (KUH Perdata pasal 1365); atau (2) memberikan disinsentif dalam bentuk pengenaan denda 
yang diberlakukan setiap tahun. Penerapan disinsentif harus didahului

dengan kajian akademis yang matang.

\section{Daftar Pustaka}

Hardjasoemantri, Koesnadi. 2002. "Hukum Tata Lingkungan". Edisi Ketujuh.

Cetakan Ketujuh belas. Gajah Mada University Press. Jogyakarta.

Marzuki, Peter, Mahmud, Prof. Dr. SH. MS. LLM. 2005. "Penelitian Hukum".

Prenada Media Group. Jakarta.

Kementrian Pekerjaan Umum. 2006. "Peraturan Menteri Pekerjaan Umum

Nomor 29/PRT/M/2006 tentang Pedoman Persyaratan Teknis Bangunan

Gedung”.

Pemerintah Republik Indonesia. 2002. "Undang-undang Nomor 28 Tahun 2002 tentang Bangunan Gedung”.

Pemerintah Republik Indonesia. 2005. "Peraturan Pemerintah Nomor 36 Tahun

2005 tentang Peraturan Pelaksanaan Undang-undang Nomor 28 Tahun

2002 tentang Bangunan Gedung”.

Pemerintah Kota Surabaya. 2009. "Peraturan Daerah Kota Surabaya 
Nomor 7

Tahun 2009 tentang Bangunan”.

Pemerintah Kota Surabaya. 2009. "Peraturan Walikota Surabaya Nomor 73

Tahun 2009 tentang Tata Cara Pengenaan Sangsi Aministratif

Pelanggaran Peraturan Daerah Kota Surabaya Nomor 7 tentang Bangunan".

jsh Jurnal Sosial Humaniora, Vol 5 No.1, Juni 2012 